\title{
Food label reading and understanding in parts of rural and urban Zimbabwe
}

\author{
P Chopera ${ }^{1}$, DT Chagwena ${ }^{1,2}$, NGT Mushonga ${ }^{1}$
}

1. Institute of Food, Nutrition and Family Sciences, University of Zimbabwe, Harare, Zimbabwe.

2. School of Pharmacy, College of Health Sciences, University of Zimbabwe, Harare, Zimbabwe

\begin{abstract}
Background: Overweight and obesity prevalence is rapidly rising in developing countries. The reading and understanding of nutrition information on food packages has been shown to improve food choices and instill healthy eating habits in individuals.

Objective: The aim of this study was to describe the prevalence of food label usage and understanding among urban and rural adults in Zimbabwe and its association with demographic and socio economic factors.

Methods: A cross sectional study was conducted on 320 adults (147 urban and 173 rural) using a validated questionnaire adapted from previous similar studies. Data were analysed using SPSS-17 statistical software.

Results: A high proportion (77.2\%) of the respondents read food labels. Food label reading differed significantly by educational status $(p<0.05)$, employment status $(p<0.05)$ and locality $(p<0.05)$. Only $40.9 \%$ of food label readers mostly understood the information on the food labels. More urban shoppers (86.1\%) read food labels than their rural counterparts $(66.7 \%)$. A significant number of participants $(80.6 \%)$ indicated they would like to be educated on the meaning of food labels and $80.3 \%$ preferred the nutrition information on food labels to be simplified.

Conclusion: The study found above average reported reading of nutrition information on food labels with partial understanding. Efforts should be made to determine how all consumers could be made to understand the nutrition information on food labels and use it effectively in decision making.
\end{abstract}

Key Words: food, labels, reading, nutrition, information

DOI: http://dx.doi.org/10.4314/ahs.v14i3.12

\section{Introduction}

The disease burden from non-communicable diseases (NCDs) is rapidly increasing in Zimbabwe and many other African countries based on projections from a few studies ${ }^{1-3}$. Diet related chronic diseases such as diabetes mellitus, cardiovascular diseases and heart disease have been reported to be among the leading cause of death and disability in developing countries ${ }^{3-5}$. It is estimated that the prevalence of diabetes mellitus in individuals between the ages of 20 to 79 years will increase from 235000 in 2010 to 389000 in $2030^{4}$. Coronary artery

\section{Corresponding author: \\ P Chopera \\ Institute of Food Nutrition and Family Sciences \\ University of Zimbabwe \\ PO Box MP 169 \\ Mt Pleasant \\ Harare, Zimbabwe \\ Email:pchopera@gmail.com \\ pchopera@science.uz.ac.zw}

disease is also reported to be on an upward trend in Sub Saharan Africans ${ }^{6}$. Diets specifically high in saturated fats, high in salt and low in fruits and vegetables have been associated with increased morbidity and mortality from these conditions ${ }^{7}$. An important modifiable factor that can reduce the prevalence of NCDs is the reduction of overweight and obesity ${ }^{8,9}$. Overweight and obesity have been associated with poor food choices and lack of physical activity ${ }^{10}$. The reading and understanding of nutrition information on food packages has been shown to improve food choices and instill healthy eating habits in individuals ${ }^{11-13}$.

The labelling of foods in most countries is subject to regulations. These regulations prevent false advertising and assist in promoting food safety. A nutrition panel on a food label is required on all packaged foods in most countries. In Zimbabwe, food labelling is governed by the Food and Food Standards Act 15:04 and Regulations of 2002. These regulations prescribe rules for any substance fit or intended for human consumption. Nutrition labelling is defined by the Act as "a description intended to inform the consumer of nutritional properties of a food". Nutrition labelling consists of two components: a nutrition declaration 
and supplementary nutrition information. Nutrition labelling is voluntary in the country and required only when nutrition or health claims are made on prepackaged foodstuffs or in food advertising. Energy, protein, fat and carbohydrates must be displayed on the nutrition information panel (NIP) of foods with claims. The Act also specifies that food labels shall be affixed on a conspicuous position on the package ${ }^{14}$. In this study the word 'reading' of food labels is used synonymously with 'usage'. Figure 1 shows an example of a food label manufacturers are required to affix on products.

Figure 1: An example of a nutrition information panel manufacturers are required to affix on products in Zimbabwe

\begin{tabular}{|l|ll|ll|}
\hline \multicolumn{3}{|c|}{$\begin{array}{c}\text { Nutritional Information } \\
\text { Serving size 1 cup (200g) } \\
\text { Servings per container 2 }\end{array}$} \\
\hline & \multicolumn{3}{c|}{ Per 100g } & Per serving (200g of yoghurt) \\
\hline Energy & 351.4 & $\mathrm{Kj}$ & 702.8 & $\mathrm{Kj}$ \\
Protein & 3.8 & $\mathrm{~g}$ & 7.6 & $\mathrm{~g}$ \\
Carbohydrate & 12.4 & $\mathrm{~g}$ & 24.8 & $\mathrm{~g}$ \\
-sugars & 9.7 & $\mathrm{~g}$ & 19.4 & $\mathrm{~g}$ \\
Total Fat & 1.7 & $\mathrm{~g}$ & 3.5 & $\mathrm{~g}$ \\
Cholesterol & 6.8 & $\mathrm{mg}$ & 13.7 & $\mathrm{mg}$ \\
Total Dietary Fiber & 0.0 & $\mathrm{~g}$ & 0.0 & $\mathrm{~g}$ \\
Sodium & 53.8 & $\mathrm{mg}$ & 107.7 & $\mathrm{mg}$ \\
Calcium & 133.4 & $\mathrm{mg}$ & 266.8 & $\mathrm{mg}$ \\
\hline
\end{tabular}

Despite the presence of an effective instrument to regulate food labelling in Zimbabwe it is unknown whether consumers use and or understand the nutrition information on food labels. The study was undertaken to provide baseline information for a nutrition education exercise targeted at adult shoppers by the Institute of Food, Nutrition and Family Sciences. To our knowledge no studies have examined food label usage and understanding in Zimbabwe. This study is the first of its kind in the country and the findings can provide useful, baseline information for healthcare professionals, the government, the food industry, the academia and consumers. In this paper, using data from a cross sectional study we have described the prevalence of food label reading and reported level of understanding amongst a sample of rural and urban consumers in Zimbabwe.

\section{Materials and methods}

This study was cross sectional in nature and conducted in the urban and rural areas surrounding Harare from May to July 2013. The study engaged respondents from three largest shopping malls in Urban Harare - Westgate, Machipisa and Eastgate and from grocery stores in
Dema, Seke and Domboshava, rural areas in the country. Respondents were approached at random as they exited from the malls and stores. Verbal consent was sought from shop owners and respondents before undertaking the study. No questionnaires were administered inside the shops as this would have disrupted normal activity and consumer behavior. Convenient sampling was used to sample 320 adults exiting supermarkets and grocery stores in the selected areas.

\section{Questionnaire Design}

Data were collected through a structured questionnaire developed based on questionnaires used reliably in previous studies ${ }^{15-18}$. The questionnaire was administered to respondents, and assessed the use and understanding of food labels. It was slightly adapted and consisted of 3 sections. Section A assessed the demographic characteristics of the respondent and whether they use nutrition labels on products. Section B examined food products that label readers consult and information of interest on the label. Section $C$ investigated the adequacy of information on the current labels and suggestions for improvements. 


\section{Statistics}

Data entry and analyses were performed using SPSS version 17 (SPSS Inc. Chicago, IL, USA). Descriptive statistics and Chi square test were generated to describe the findings. Incomplete questionnaires were not used in the final analysis.

\section{Results}

General characteristics of the respondents

A total of 320 individuals participated in the survey, comprising 147 urban and 173 rural consumers. The majority of respondents were females $(51.6 \%)$ aged between 18- 30 years, with secondary level of education. The remaining general characteristics of the study participants are presented in Table 1.

Table 1: Description of food label readers and non-readers

\begin{tabular}{|c|c|c|c|}
\hline Characteristic & & $\begin{array}{l}\text { Non label readers } \\
(\%)\end{array}$ & $\begin{array}{l}\text { Label readers } \\
(\%)\end{array}$ \\
\hline All individuals & $\mathrm{N}=320$ & 22.8 & 77.2 \\
\hline \multicolumn{4}{|l|}{ Sex } \\
\hline Male & $\mathrm{N}=138$ & 27.5 & 72.5 \\
\hline Female & $\mathrm{N}=165$ & 19.4 & 80.6 \\
\hline \multicolumn{4}{|l|}{ Age group } \\
\hline$<18$ & $N=26$ & 15.4 & 84.6 \\
\hline $19-30$ & $\mathrm{~N}=153$ & 22.9 & 77.1 \\
\hline $31-50$ & $\mathrm{~N}=111$ & 24.3 & 75.7 \\
\hline$>51$ & $\mathrm{~N}=25$ & 28 & 72 \\
\hline \multicolumn{4}{|l|}{ Education status* } \\
\hline None & $\mathrm{N}=1$ & 0 & 100 \\
\hline Primary & $N=20$ & 55 & 45 \\
\hline Secondary & $\mathrm{N}=186$ & 24.7 & 75.3 \\
\hline $\begin{array}{l}\text { post secondary } \\
\text { Employment status* }\end{array}$ & $\mathrm{N}=89$ & 13.5 & 86.5 \\
\hline Student & $\mathrm{N}=39$ & 12.8 & 87.2 \\
\hline Unemployed & $\mathrm{N}=116$ & 31.9 & 68.1 \\
\hline Employed & $N=156$ & 18.6 & 81.4 \\
\hline \multicolumn{4}{|l|}{ Income per month } \\
\hline$<\mathrm{US} \$ 400$ & $\mathrm{~N}=101$ & 17.8 & 82.2 \\
\hline US\$401-500 & $\mathrm{N}=39$ & 15.4 & 84.6 \\
\hline US\$501-1000 & $N=25$ & 24.0 & 76 \\
\hline US\$1001-1500 & $\mathrm{N}=12$ & 16.7 & 83.3 \\
\hline $\mathrm{US} \$>1501$ & $\mathrm{~N}=15$ & 20.0 & 80 \\
\hline \multicolumn{4}{|l|}{ Marital Status } \\
\hline Single & $\mathrm{N}=105$ & 20.9 & 79.1 \\
\hline Married & $\mathrm{N}=185$ & 24.3 & 75.7 \\
\hline Divorced & $N=7$ & 14.3 & 85.7 \\
\hline Widowed & $\mathrm{N}=15$ & 20 & 80 \\
\hline \multicolumn{4}{|l|}{ Residential Status } \\
\hline Low & $N=64$ & 20.3 & 79.7 \\
\hline Medium & $\mathrm{N}=125$ & 21.6 & 78.4 \\
\hline High & $\mathrm{N}=89$ & 16.8 & 83.2 \\
\hline \multicolumn{4}{|l|}{ Locality* } \\
\hline Rural & $\mathrm{N}=147$ & 33.3 & 66.7 \\
\hline Urban & $\mathrm{N}=173$ & 13.9 & 86.1 \\
\hline
\end{tabular}

*Differences between groups are statistically significant at $\mathrm{p}<0.05$ based on chi-square test. 
Results do not add up to 320 due to missing responses

\section{Food Label reading}

More females $(80.6 \%)$ than males $(72.5 \%)$ were food label readers however the difference was not significant. Label reading increased with educational status, with the majority of students $(87.2 \%)$ and employed people $(81.4 \%)$ being label readers. Food label usage decreased with increasing age group however the difference was not significant between the groups. There was a significant difference between label usage and residential area. More urban shoppers $(86.1 \%)$ read labels than their rural counterparts $(66.7 \%)$.

\section{Reasons for reading food labels}

Buying a product for the first time was identified as one of the major reasons for reading food labels by $27.8 \%$ of the respondents (Figure 2).

Figure 2: Bar graph indicating when respondents read food labels

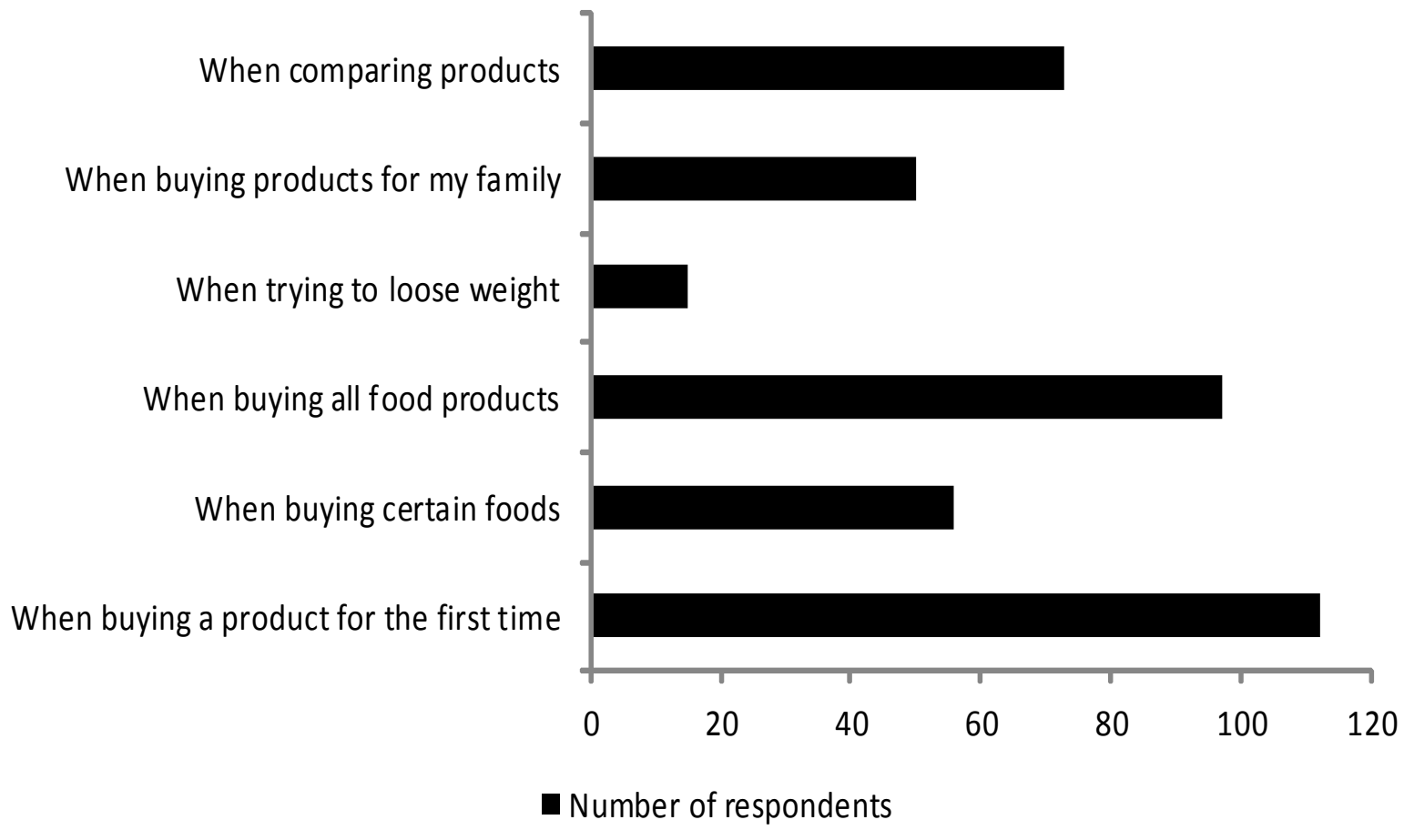

Fewer respondents read labels when comparing products $(18 \%)$, when buying certain food products Generally urban respondents mostly read food labels $(13.8 \%)$, when purchasing food for the family $(12.4 \%)$, when purchasing a product for the first time and most and when observing specific diet to lose weight (3.7\%). rural respondents reported that they would read a label when trying to lose weight (Table 2). 


\begin{tabular}{|c|c|c|c|c|c|}
\hline & $\begin{array}{l}\text { Urban } \\
\mathrm{N}\end{array}$ & $\%$ & $\begin{array}{c}\text { Rural } \\
\mathrm{N}\end{array}$ & $\%$ & Total N \\
\hline \multicolumn{6}{|l|}{ When do you read food labels? } \\
\hline $\begin{array}{l}\text { When buying a product for the first } \\
\text { time }\end{array}$ & 73 & 65.2 & 39 & 34.8 & 112 \\
\hline When buying certain foods & 32 & 57.1 & 24 & 42.9 & 56 \\
\hline When buying all foods & 57 & 58.8 & 40 & 41.2 & 97 \\
\hline When trying to lose weight & 7 & 46.7 & 8 & 53.3 & 15 \\
\hline When buying products for my family & 24 & 48.0 & 26 & 52.0 & 50 \\
\hline When comparing products & 45 & 61.6 & 28 & 38.4 & 73 \\
\hline \multicolumn{6}{|l|}{$\begin{array}{l}\text { Which food constituent is of interest on } \\
\text { labels }\end{array}$} \\
\hline Calories & 55 & 62.5 & 33 & 37.5 & 88 \\
\hline Fats & 76 & 72.4 & 29 & 27.6 & 105 \\
\hline Total carbohydrates & 41 & 54.7 & 34 & 45.3 & 75 \\
\hline Sugars & 49 & 60.5 & 32 & 39.5 & 81 \\
\hline Protein & 39 & 54.9 & 32 & 45.1 & 71 \\
\hline Sodium & 29 & 58.0 & 21 & 42.0 & 50 \\
\hline Vitamins & 41 & 47.1 & 46 & 52.9 & 87 \\
\hline Minerals & 28 & 45.2 & 34 & 54.8 & 62 \\
\hline Preservatives & 81 & 65.3 & 43 & 34.7 & 124 \\
\hline \multicolumn{6}{|l|}{$\begin{array}{l}\text { Factors considered when buying food } \\
\text { products }\end{array}$} \\
\hline Ingredients & 90 & 56.3 & 70 & 43.8 & 160 \\
\hline Net volume/weight & 40 & 48.8 & 42 & 51.2 & 82 \\
\hline Date of expiry & 136 & 56.2 & 106 & 43.8 & 242 \\
\hline Taste & 52 & 52.0 & 48 & 48.0 & 100 \\
\hline Price & 95 & 55.6 & 76 & 44.4 & 171 \\
\hline Storage conditions & 70 & 51.9 & 65 & 48.1 & 135 \\
\hline Instructions of use & 76 & 53.5 & 66 & 46.5 & 142 \\
\hline
\end{tabular}

Food constituents of interest to the label readers Of interest to most respondents rural and urban combined were the levels of preservatives and chemicals in any particular food or drink they were purchasing
$(16 \%)$ (Figure 3). Other constituents respondents were interested in were nutrients, including fat $(14 \%)$, vitamins $(11.7 \%)$, calories $(11.8 \%)$, total carbohydrates $(10.1 \%)$, sugars $(10.9 \%)$, protein $(9.5 \%)$ and sodium $(6.7 \%)$. 
Figure 3: Bar graph showing the type of food constituents label readers specifically targeted on food labels

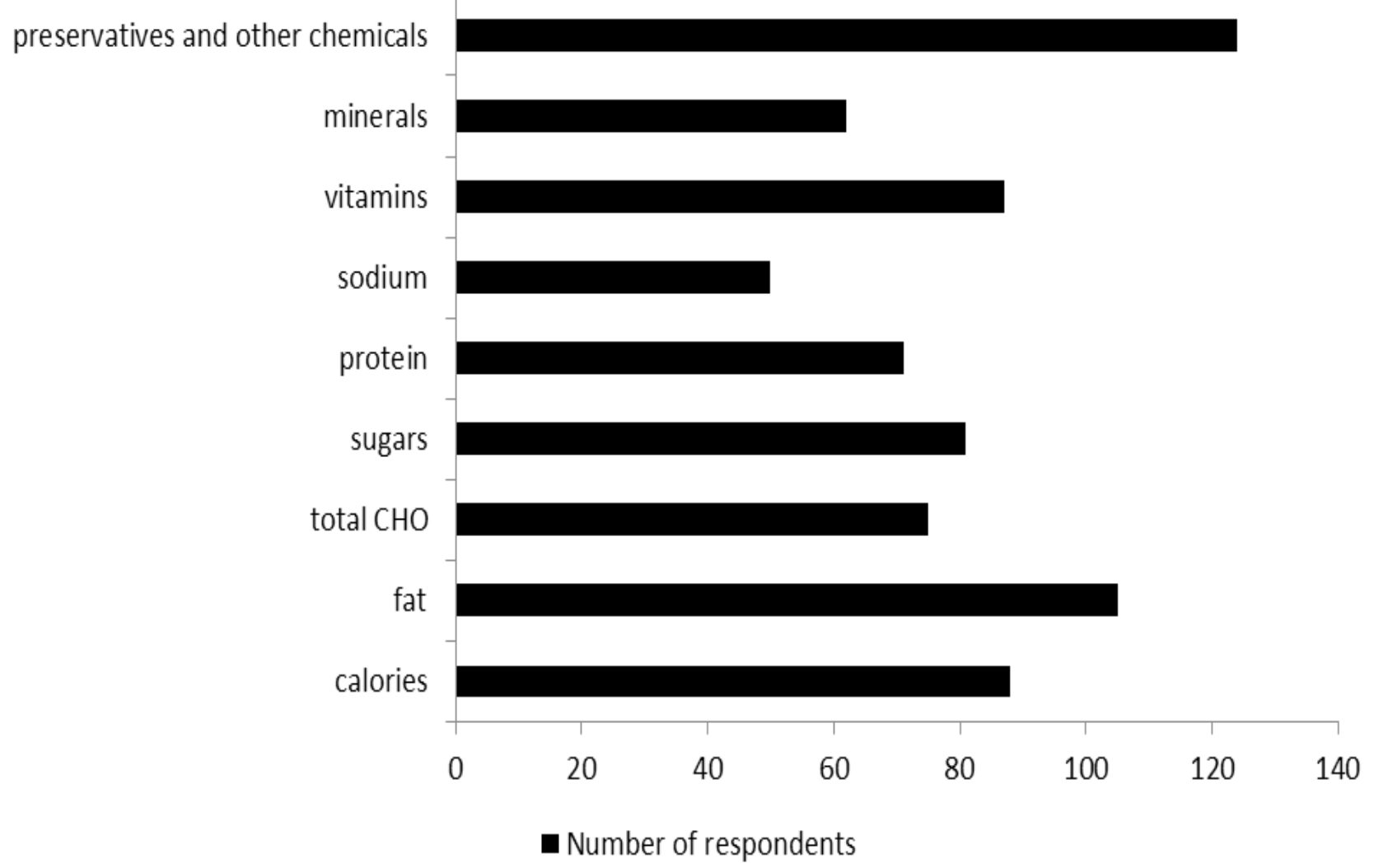

Urban respondents mostly looked for fat content on rural counterparts considered net weight or volume of food labels whilst rural respondents mostly looked for minerals and vitamins on labels (Table 2).

\section{Factors considered when purchasing a food product}

A significant number of participants considered the expiry date as important when purchasing a food product $(23.4 \%)$ (Figure 4$)$.

Ingredients $(15.5 \%)$ and price $(16.6 \%)$ were the second most important factors to consider when purchasing a food product. An almost equal number of respondents considered storage conditions (13.1\%), and instructions of use $(13.8 \%)$ as also important. Urban respondents considered ingredients and date of expiry as important factors when purchasing food products whilst their a food product (Table 2).

\section{Understanding of food labels}

Of the label readers, less than half of the respondents $(40.9 \%)$ claimed to 'mostly understand' nutrition labels, while 51\% reported partial understanding. Most individuals who participated in the survey $(80.6 \%)$ suggested the need for education on food labels. A total of $80.3 \%$ preferred food labels to be simplified. A small percentage $(7.5 \%)$ did not want them to be simplified and $7.2 \%$ did not 'really care'. More than half of the respondents (54\%) said food labels provided adequate information. On 'any other information respondents would like declared on food products', 5.5\% requested for valid, truthful food labels, $8.6 \%$ would like allergens declared on labels and 3.5\% requested to have more details on food labels. 
Figure 4: Bar graph showing factors the shoppers considered before purchasing any food item

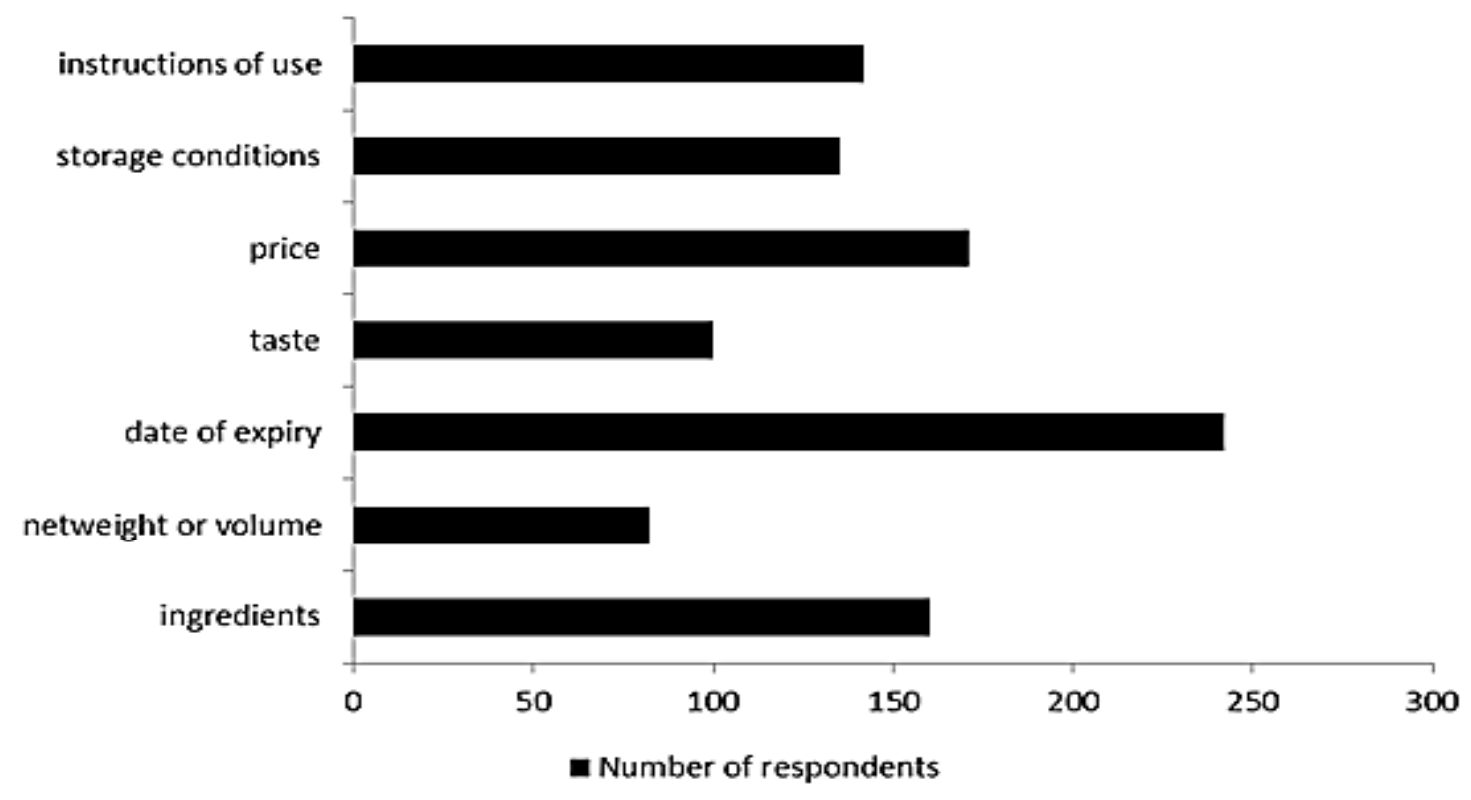

\section{Discussion}

The results showed that the majority of the respondents read labels $(77.2 \%)$, with partial understanding (51\%). Most of the respondents were not familiar with the terminology and language used and requested for some form of education $(80.6 \%)$ and simplification of labels $(80.3 \%)$. Figures much lower than these have been reported in studies conducted elsewhere. For example, one study in Malawi found low usage (29.1\%) and low understanding $(26.2 \%)$ of nutrition labels ${ }^{16}$, while another study in South Africa reported nutrition label use of $55 \%{ }^{19}$. Figures from the developed world show much high prevalence of food label reading. A study in America found at least $80 \%$ of consumers usually or often read nutrition labels ${ }^{12}$. Another study conducted among African Americans found $78 \%$ of consumers read nutrition information on labels ${ }^{20}$. A review of 15 European countries revealed the following prevalences of food label reading; UK 52\%, Ireland 65\%, Sweden $50 \%$ and France $63 \%{ }^{21}$. The reading may be high in Zimbabwe compared to Malawi (29.1\%) and South Africa $(55 \%)$ due to high literacy rates in Zimbabwe estimated at $90.7 \%{ }^{22}$. However the figures should be interpreted with caution across studies in view of the self-reported measures used to assess utilization and understanding of nutrition information on products. The study found that urban and female consumers were more inclined to read food nutrition labels than their counterparts, a finding that is consistent with the results from previous studies by various researchers. Rural consumers or individuals with low socio economic status tend to attach more importance to price and are less likely to consult labels ${ }^{23}$. A number of studies in the UK, U.S., Australia and Sri Lanka have also found that women read labels more than men ${ }^{12,24-29}$. This may be because men are less likely to agree on the usefulness of nutrition information on labels and in general have been shown to display less interest in nutrition and health issues compared to women ${ }^{26}$.

Of highest interest to most respondents both rural and urban, were the levels of preservatives and chemicals in any particular food or drink they were purchasing (Figure 4).

Sixteen percent $(16 \%)$ of the respondents cited these as the constituents they are most interested in on food labels. Only $14 \%$ of all respondents were interested in the fat content. In terms of nutrients, fats and or calories are nutrients frequently cited in most studies as nutrients of interest on food labels ${ }^{30}$.

There was little interest in sodium (6.7\%) arguably because consumers may not be aware of the association between cardiovascular disease and salt intake ${ }^{31}$. The real reasons will need further investigations. Urban 
respondents mostly looked for fat content on food labels whilst rural respondents mostly looked for minerals and vitamins on labels. The link between high calorie intake and obesity has well been explained in literature readily accessible to urban respondents and it is this knowledge that could be influencing the choices made by urban respondents. Rural respondents considered net weight or volume of a food product whilst urban respondents considered ingredients and date of expiry as important factors when purchasing food products. This may have been influenced by rural respondent's quest for value for money ${ }^{23}$.

The major strength of the study was that respondents and supermarkets were selected from both rural and urban areas randomly. However this study has some limitations. Firstly the small sample size may mean that the results are not generalizable. Further research is required with a larger sample size to make the results conclusive rather than suggestive. Secondly, the study made use of self-reports, and as a result consumers may have reported intended rather than actual shopping behaviours.

Despite these limitations the findings of this study have some public health implications. High levels of reading with limited understanding of nutrition information on food labels may mean that more effort should be made in making simplified labels or in consumer education. Barriers to reading labels and the actual usage of the labels in guiding purchase decisions need to be investigated. The socio demographic differences with regard to food label use must assist public health care professionals in channeling interventions to those groups in need. Low levels of reading food labels in rural areas mean that public health efforts should be channeled towards education of rural consumers about nutrition labels.

\section{Conclusion}

The study found high prevalence of reading with partial understanding of the nutrition information on food labels in both rural and urban Zimbabwe. Efforts should be made to determine how all consumers could be made to understand and use food labels effectively.

\section{References}

1. Mufunda J, Chatora R, Ndambakuwa Y, Nyarango P, Chifamba J, Kosia A, et al. Prevalence of Non Communicable Diseases in Zimbabwe: Results from Analysis of Data from the National Central Registry and Urban
Survey. Ethnicity and Disease 2006;16:718-22.

2. Hall V, Thomsen RW, Henriksen O, Lohse N. Diabetes in Sub Saharan Africa 1999-2011: Epidemiology and Public Health Implications. A Systematic Review. BMC Public Health 2011;11:564.

3. Mensah GA. Ischaemic Heart Disease in Africa. Heart (British Cardiac Society) 2008;94:836-43.

4. Shaw JE, Sicree RA, Zimmet PZ. Global Estimates of the Prevalence of Diabetes for 2010 and 2030. Diabetes Research and Clinical Practice 2010;87:4-14.

5. Trowell HC and Burkitt DP. Western Diseases: Their Emergence and Prevention. Harvard University Press; Havard.1981.

6. Akinboboye $\mathrm{O}$, Idris $\mathrm{O}$, Akinkugbe $\mathrm{O}$. Trends in Coronary Artery Disease and Associated Risk Factors in sub-Saharan Africans. Journal of Human Hypertension 2003;17:381-7.

7. Danaei G, Ding EL, Mozaffarian D, Taylor B, Rehm J, Murray CJL, et al. The Preventable Causes of Death in the United States: Comparative Risk Assessment of Dietary, Lifestyle, and Metabolic Risk Factors. PLoS Medicine 2009;6(4):e1000058. doi:10.1371/journal. pmed.1000058

8. Waxman A. WHO's Global Strategy on Diet, Physical Activity and Health. Response to a Worldwide Epidemic of Non-Communicable Diseases. Food \& Nutrition Research 2004;48:58-60.

9. Beaglehole R, Bonita R, Horton R, Adams C, Alleyne G, Asaria P, et al. Priority Actions for the Non-Communicable Disease Crisis. Lancet 2011;377:1438-47.

10. Mela DJ. Determinants of Food Choice: Relationships with Obesity and Weight Control. Obesity Research 2001;9 Suppl 4:249S-255S.

11. Guthrie JF, Fox JJ, Cleveland LE, Welsh S. Who uses Nutrition Labelling, and What Effects Does Label Use Have on Diet Quality? Journal of Nutrition Education 1995;27:163-72.

12. Neuhouser ML, Kristal AR, Patterson RE. Use of Food Nutrition Labels is Associated with Lower Fat Intake. Journal of the American Dietetic Association 1999;99:45-53.

13. Campos S, Doxey J, Hammond D. Nutrition Labels on Pre-packaged Foods: a systematic review. Public Health Nutrition 2011;14:1496-506.

14.http://www.parlzim.gov.zw/attachments /

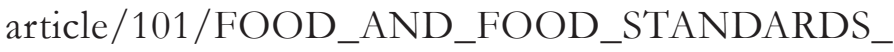
ACT_15_04.pdf. (Accessed on 2 September 2013) 15. Parmenter K and Wardle J. Development of a General Nutrition Knowledge Questionnaire for Adults. European Journal of Clinical Nutrition 1999;53:298-308. 
16. Kasapila W and Shawa P. Use and Understanding of Nutrition Labels Among Consumers in Lilongwe (Malawi). African Journal of Food, Agriculture, Nutrition and Development 2011;11:5171-5186

17. Nørgaard MK and K Brunsø. Families' Use of Nutritional Information on Food Labels. Food Quality and Preference 2009;20:597-606.

18. Grunert KG, Fernaández-Celemín L, Wills JM BS and LN. Use and Understanding of Nutrition Information on Food Labels in Six European Countries. Journal of Public Health 2010.

19. Wiles NL, Paterson M, Meaker JL. What Factors Determine the Use of the Nutrition Information on the Food Label when Female Consumers from Pietermaritzburg Select and Purchase Fat Spreads? South African Journal of Clinical Nutrition 2009;22.

20. Satia JA, Galanko JA, Neuhouser ML. Food Nutrition Label use is Associated with Demographic, Behavioral, and Psychosocial Factors and Dietary intake among African Americans in North Carolina. Journal of the American Dietetic Association 2005;105:392-402; discussion 402-3.

21. Grunert KG, Wills JM. A Review of European Research on Consumer Response to Nutrition Information on Food Labels. Journal of Public Health 2007;15:38599.

22.http:/ / theafricaneconomist.com/ranking-of-african-countries-by-literacy-rate-zimbabwe-no-1/\# .
UvOdbbTtiVo (Accessed on 6 February 2013)

23. Drichoutis A, Laziridis R, Nayga R. Consumer's Use of Nutritional Labels: A Review of Research Studies and Issues. Academy of Marketing Sciences Reviews 2006;9. 24. Prathiraja PHK, Ariyawardan A. Impact of Nutritional Labelling on Consumer Buying Behaviour. Sri Lankan Journal of Agricultural Economics 2003;5:35-46.

25. Hawkes C. Nutrition Labels and Health Claims:The Global Regulatory Environment, WHO.2004.

26. Nagya R. Towards an Understanding of Consumer's Perceptions of Food Labels. International Food and Agribusiness Management Review 1999;2:29-45.

27. Nagya R. Impact of Socio-Demographic Factors on Perceived Importance of Nutrition in Food Shopping. Journal of Consumer Affairs 1997;31:1-9.

28. Cowburn G, Stockely L. A Systematic Review of the Research on Consumer Understanding of Nutrition Labelling. European Heart Network, 2003.

29. Ipsos RSL (2000) Consumer Attitudes to Food Labelling Report, Ministry of Agriculture, Fisheries and Food (MAFF).

30. EdComs. Review and Analysis of Current Literature on Consumer Understanding of Nutrition and Health Claims Made on Food. London, 2007.

31. Strazzullo P, D’Elia L, Kandala N-B, Cappuccio FP. Salt Intake, Stroke, and Cardiovascular Disease: Metaanalysis of Prospective Studies. BMJ (Clinical Research Ed) 2009;339:b4567. 